\title{
Hindistan Cevizi Unu ile Zenginleştirilmiş Dut Pestillerinin Bazı Fizikokimyasal, Renk ve Duyusal Özelliklerinin İncelenmesi
}

\author{
Investigation of Some Physicochemical, Color and Sensory Properties of Mulberry Pestils \\ Enriched with Coconut Flour
}

\author{
Ferhat YÜKSEL*a ${ }^{*}$ Büşra YAVUZ ${ }^{\mathrm{b}}$, Cemalettin BALTACI ${ }^{\mathbf{c}}$ \\ Gümüşhane Üniversitesi, Mühendislik ve Doğa Bilimleri Fakültesi, Gıda Mühendisliği Bölümü, 29100, Gümüşhane
}

• Geliş tarihi / Received: 28.03.2019 • Düzeltilerek geliş tarihi / Received in revised form:23.09.2019 • Kabul tarihi / Accepted: 4.10.2019

\begin{abstract}
$\ddot{\mathbf{O} z}$
$\mathrm{Bu}$ çalışmanın amacı farklı konsantrasyonlarda (0-2-4 ve $5 \mathrm{~g} / 100 \mathrm{~g})$ Hindistan cevizi unu ile zenginleştirilmiş dut pestillerinin bazı fizikokimyasal, renk ve duyusal özelliklerini araştırmaktır. Zenginleştirilmiş herle örnekleri şekil verilmesinin (bezlere serilmesi) ardından kurutulmuş ve analizleri gerçekleştirilmiştir. Pestillerin nem değerleri 11.65$21.39 \mathrm{~g} / 100 \mathrm{~g}$ aralığında değişmiş ve Hindistan cevizi unu ilavesiyle istatistiksel olarak anlamlı $(\mathrm{p}<0.01)$ bir artma bulunmuştur. Hindistan cevizi unu ilavesiyle örneklerin viskozite değerleri önemli $(p<0.01)$ oranda azalmıştır. Örneklerin hidroksimetilfurfural (HMF) değerleri 11.64 ile $21.55 \mathrm{mg} / \mathrm{kg}$ aralığında belirlenmiştir. En yüksek sakkaroz içeriği 1 numaralı örnekte (\% 27.63) belirlenirken düşük sakkaroz ise 2 numaralı örnekte (\%24.61) tespit edilmiştir. Örneklerin renk/görünüş, sertlik/yumuşaklık, yapışkanlık ve genel beğeni testleri arasında anlamlı bir farklılık tespit edilmemişken $(p>0.05)$ koku/tat skorları arasında anlamlı $(p<0.05)$ bir fark belirlenmiştir. Genel olarak 2. dizayn $(2$ $\mathrm{g} / 100 \mathrm{~g}$ Hindistan cevizi unu içeren) panelistler tarafından en beğenilen deneme tasarımı olarak bulunmuştur. $\mathrm{Bu}$ çalışmada Hindistan cevizi unu kullanılarak daha yumuşak, genel kabul görmüş ve alternatif bir pestil üretilebileceği görülmüştür.
\end{abstract}

Anahtar kelimeler: Hindistan Cevizi Unu, HMF ve Duyusal Analiz, Pestil, Şeker, Viskozite

\begin{abstract}
The aim of this study was to investigate some physicochemical, color and sensory properties of mulberry pestils enriched with coconut flour at four different concentrations $(0-2-4$ and $5 \mathrm{~g} / 100 \mathrm{~g})$. Following shaping of the enriched herle samples were dried and analyses were conducted. Moisture values of the pestils were in the range of 11.65-21.39 $g / 100 g$ and increased significantly $(p<0.01)$ with the addition of coconut flour. Viscosity values of samples decreased significantly $(p<0.01)$ with the addition of coconut flour. The HMF contents of samples were determined in the range of $11.64-21.55 \mathrm{mg} / \mathrm{kg}$. Maximum sucrose content $(27.63 \%)$ was found at 2 nd sample while minimum sucrose content $(24.61 \%)$ was determined at 1th sample. No significant difference was determined for the colorlappearance, firmness/softness, stickiness and overall acceptability scores of the samples $(p>0.05)$ while there was significant difference smell/taste scores ( $p<0.05$ ). Generally, the best of the trying of design was found to be 2nd design (included $2 \mathrm{~g} / 100 \mathrm{~g}$ coconut flour) by panelists. In this study, it was seen that a softer, generally accepted and alternative pestil can be produced by using coconut flour.
\end{abstract}

Keywords: Coconut Flour, HMF and Sensory Analysis, Pestil, Sugar, Viscosity

\footnotetext{
${ }^{*}$ Farhat YÜKSEL; fyuksel@gumushane.edu.tr, Tel: (0456) 23375 43/1862, (0456) 233 75 67, orcid.org/0000-0003-1995-9820

${ }^{b}$ orcid.org/0000-0001-7404-7061 $\quad{ }^{\mathrm{c}}$ orcid.org/0000-0002-4336-4002
} 


\section{Giriş}

Dut pestili ve kömenin coğrafi işaretinin alındığ il olan Gümüşhane'de pestil ve köme sektörü her geçen gün hızla büyümektedir (TPE., 2014). Gümüşhane'de toplam pestil ve benzeri ürünlerin üretimi 2009 y1lında 2.968,02 kg iken 2017 y1lında bu oran yılda yaklaşık 5 bin ton olduğu tahmin edilmekte ve 250 ile 300 kişiye istihdam sağlamaktadır (Berksoy vd., 2016; URL-1 2017). Pestil üretiminde genelde şu malzemeler kullanılmaktadır; su, dut pekmezi, buğday unu/nişasta, şeker, bal, pekmez ve süt. Dut pekmezinin şeker, süt, pekmez ve bal ile karıştırılarak kaynatıldıktan sonra içerisine buğday ununun ya da nişastasının ilavesi ile elde edilen jelimsi kıvamlı yapının (herle) uygun şartlarda kurutulmasına (nem oranı en çok $18 \mathrm{~g} / 100 \mathrm{~g})$ kadar uzanan bir seri işlemler ile pestil üretimi gerçekleştirilmektedir (Baltacı vd., 2016; Y1ld1z, 2013).

Pestil üretiminde tahıl bazlı bileşenler (Buğday unu, nişasta) önemli bir yer tutmaktadır (Becerikli ve Başoğul, 2018). Özellikle pestilin jelimsi hali olan herlenin oluşumunda ve bezlere serilmesinde tahıl bazlı bileşenlerin etkisi çok önemlidir. $\mathrm{Bu}$ jelimsi halinin (herle) oluşmasında formülasyondaki buğday unu ya da nişastanın jelatinizasyon derecelerinin üzerinde kaynatılıp viskozitesinin artması, kıvamlı bir hal alması ve bu sayede de herleye istenen şeklin verilmesi pestil üretiminin önemli bir aşamasıdır. Gümüşhane pestilini diğerlerinden ayıran en önemli nokta kullanılan bu tahıl bazlı bileşende yatmaktadır. Genelde Gümüşhane'de üretilen pestillerde ekmeklik buğday unu tercih edilirken, Gümüşhane dış1 şehirlerde yapılan üretimlerin çoğunda nişasta tercih edilmektedir. Bu da üründe bazı yapısal farklılıkların ortaya çıkmasına sebep olmaktadır (Kalkışım ve Özdemir, 2012). Nitekim Gümüşhane pestilinin tüketicilerden oldukça fazla rağbet görmesinin en önemli sebeplerinden birisinin yapısal farklılık olduğu belirtilmektedir. Üreticiler son y1llarda artan maliyetlerin etkisi ve ürünü daha yumuşak tutması sebebiyle bal yerine sıvı şeker ve glukoz şurubu tercih etmektedirler. Ayrıca Gümüşhane pestilinde kullanılan tahıl bazlı bileşenler farkından (tam nişasta unu yerine buğday unu) dolayı da diğerlerine göre daha yumuşak olduğu ve tüketicileri etkilediği söylenebilir.

Gümüşhane pestil üreticilerin karşılaştı̆̆ bazı sorunlar bulunmaktadır. Pestil ve ürünlerindeki çatlamalar ve kırılmalar ile ürünün raf ömrü bu sorunlar arasindadır. Bu sorunların sebebi olarak üretim metodu, ambalaj ve pestil kalınlığı dışında içerisinde kullanılan tatlandırıcılar (bal, sıvı şeker ve glukoz şurubu) ve tahıl bazlı bileşenlerin olduğu söylenebilir. Pestil üretiminde 80-90 ${ }^{\circ} \mathrm{C}$ 'lerde yapılan kaynatma sonrası oluşan herle bezlere serilmekte ve kurutulmaktadır. Kullanılan bu yüksek ısının etkisi ile ürün içindeki un ya da nişasta jelatinize olmakta ve kıvamlı bir hal alarak şekil verilmesini sağlamaktadır (Ekşi ve Artık, 1984; Batu vd., 2007). Bundan sonraki aşama olan kurutmada nem kaybı ile başlayan retrogradasyon işlemi ile pestil oluşmaktadır. Depolamaya bağlı olarak yapisinda bu retrogradasyon olayı devam etmekte ve pestilin yapısı daha da sertleşmektedir ve tüketilemez hale gelmektedir. Bu sorunu önlemede üreticiler formülasyonda un ya da nişasta oranını azaltma ile pestil yüzeyine yağ gibi bir madde sürerek bariyer oluşturup ürünün nem kaybını engellemekte ve yumuşaklığını daha uzun süre koruyarak raf ömrünü artırmaya çalışmaktadırlar (Kalkışım ve Özdemir, 2012). Fakat ürün formülasyonundaki tahıl bazlı bileşenlerin bu sorun üzerindeki sorumluluğu hakkında yapılan çalışma yok denecek kadar azdır. Kullanılan bu tahıl bazlı bileşenlerin farklı unlar ile değerlendirilerek üründeki bu sorunlar üzerine etkilerinin araştırılması ve alternatif üretimlerin sektöre kazandırılması gerekmektedir.

Palmiye ağacının bir meyvesi olan Hindistan cevizi (Cocos nucifera L.) tropikal ve sutropikal bölgelerdeki milyonlarca insan için önemli bir gıda kaynağıdır. Dünyadaki en önemli üreticileri arasında Filipinler, Seylan adas1, Hindistan, Malezya, Okyanusya, Nijerya ve bazı batı Afrika ülkeleri yer almaktadır. Hindistan cevizi meyvesinin her kısmı kullanılabilmekte ve insan sağlığına olumlu birçok fayda sağlayacak bileşenler içermektedir. $\mathrm{Bu}$ bileşikler şunlardır; kalsiyum, B gurubu vitaminleri (B1, B3, B5 ve B6), şeker, C vitamini, folik asit, diyet lifi. Hindistan cevizi unu meyveden Hindistan cevizi sütü elde edildikten sonra artakalan kısımdan üretilmektedir. Hindistan cevizi unu karbohidrat ailesinden olan diyet lifleri içermesi ve nişasta içermeyen polisakkaritler içermesi sayesinde ince bağırsakta sindirilmez ve kalın bağırsaktaki faydalı bakterilerce fermente edilerek vücut için yararlı kısa zincirli yağ asitlerinin üretimine katkı yapar. Hindistan cevizi ununun içerdiği bu özellikler, katkılandığı gıdalara önemli bir fonksiyonellik kazandırabilecektir (Amoo, 2004; Trinidad vd, 2006; Igbabul vd., 2014; Zhenga ve Lia, 2018). 


\section{Amaç}

$\mathrm{Bu}$ çalışmada Hindistan cevizi unu ile zenginleştirilmiş dut pestillerine bazı fizikokimyasal (nem, aw, kül, yağ, toplam şeker, HMF), renk $\left(L^{*}, a^{*} v e b^{*}\right)$, viskozite ve duyusal (renk/görünüş, tat/koku, sertlik/yumuşaklık, yapışkanlık ve genel beğeni) testler uygulanmıştır. $\mathrm{Bu}$ çalışma ile pestil üretiminde kullanılan ekmeklik buğday unu konsantrasyonu azaltılıp bunun yerine Hindistan cevizi unu eklenerek besinsel içeriği artırılmış, sertliği azaltılmış, duyusal anlamda genel kabul görmüş ve pestil sektörüne alternatif yeni bir pestil ürünü kazandırılması amaçlanmıştır.

\section{Gereç ve Yöntem}

\subsection{Materyal ve Metot}

Çalışmada kullanılan Hindistan cevizi unu internetten temin edilmiştir (www.amazon.com). Pestil üretiminde ekmeklik buğday unu (Sinangil, Turkey) (nem; $12.93 \mathrm{~g} / 100 \mathrm{~g}$, yăg; $2.86 \mathrm{~g} / 100 \mathrm{~g}$, protein; $11.10 \mathrm{~g} / 100 \mathrm{~g}, \quad$ kül;1.81 $\mathrm{g} / 100 \mathrm{~g}$ ) kullanılmıştır. Bob red mill marka Hindistan cevizi unu (nem; $3.20 \mathrm{~g} / 100 \mathrm{~g}$, kül; $5.28 \mathrm{~g} / 100 \mathrm{~g}$, yăg; $14.28 \mathrm{~g} / 100 \mathrm{~g}$, protein; $14.28 \mathrm{~g} / 100 \mathrm{~g}$ ) çalışmada kullanılmıştır. Şeker, dut pekmezi, çiçek balı ve tam yağlı süt bölgesel marketlerden temin edilmiştir (Gümüşhane, Türkiye).

\subsection{Pestil Üretimi}

Pestil üretimi Tablo 1'de belirtilen formülasyon ile Şekil 1'de belirtilen akım şemasına göre gerçekleştirilmiştir. Pestil üretimi için kullanılan hammaddelerin formülasyon oranları şu şekildedir; $70 \mathrm{~g} / 100 \mathrm{~g} \mathrm{su}, 10 \mathrm{~g} / 100 \mathrm{~g}$ un (1. örnek: $10 \mathrm{~g} / 100 \mathrm{~g}$ buğday, $0 \mathrm{~g} / 100 \mathrm{~g}$ Hindistan cevizi unu; 2.örnek: $8 \mathrm{~g} / 100 \mathrm{~g}$ buğday unu, $2 \mathrm{~g} / 100 \mathrm{~g}$ Hindistan cevizi unu; 3.örnek: $6 \mathrm{~g} / 100 \mathrm{~g}$ buğday unu, 4 g/100g Hindistan cevizi unu; 4.örnek 5 g/ 100g buğday ve Hindistan cevizi unu), $9 \mathrm{~g} / 100 \mathrm{~g}$ şeker, $1.5 \mathrm{~g} / 100 \mathrm{~g}$ bal (çiçek), $6.5 \mathrm{~g} / 100 \mathrm{~g}$ süt ve 3.0 $\mathrm{g} / 100 \mathrm{~g}$ dut pekmezi (1-2-3 ve 4 nolu deneme noktalarında un hariç diğer komponentlerin miktarlar1 aynı) (Tablo 1.). Şekil 1 de verilen yönteme göre elde edilen pestiller oda şartlarında ağzı kapalı saklama kaplarında muhafaza edilerek tüm analizleri gerçekleştirilmiştir. Örneklere ait herleler bezlere serilmeden önce viskozite tayinleri $\left(70 \pm 3{ }^{\circ} \mathrm{C}\right)$ yapılmışıtır.

Tablo 1. Örneklerin üretim formülasyonu

\begin{tabular}{cccccccc}
\hline Örnek & $\begin{array}{c}\text { Buğday } \\
\text { unu } \\
(\mathrm{g} / 100 \mathrm{~g})\end{array}$ & $\begin{array}{c}\text { Hindistan } \\
\text { cevizi unu } \\
(\mathrm{g} / 100 \mathrm{~g})\end{array}$ & $\begin{array}{c}\text { Su } \\
(\mathrm{g} / 100 \mathrm{~g})\end{array}$ & $\begin{array}{c}\text { Bal } \\
(\mathrm{g} / 100 \mathrm{~g})\end{array}$ & $\begin{array}{c}\text { Seker } \\
(\mathrm{g} / 100 \mathrm{~g})\end{array}$ & $\begin{array}{c}\text { Süt } \\
(\mathrm{g} / 100 \mathrm{~g})\end{array}$ & $\begin{array}{c}\text { Pekmez } \\
(\mathrm{g} / 100 \mathrm{~g})\end{array}$ \\
\hline 1 & 10 & 0 & 70 & 1.5 & 9 & 6.5 & 3 \\
2 & 8 & 2 & 70 & 1.5 & 9 & 6.5 & 3 \\
3 & 6 & 4 & 70 & 1.5 & 9 & 6.5 & 3 \\
4 & 5 & 5 & 70 & 1.5 & 9 & 6.5 & 3 \\
\hline
\end{tabular}

\subsection{Fizikokimyasal Analizler}

Pestil örneklerine ait bazı fizikokimyasal analizler için AOAC (2000) deki metot kullanılmıştır. Parçalanmış pestil örneklerine ait nem içerikleri için önceden $105{ }^{\circ} C^{\prime}$ ye ayarlanmış etüvde yaklaşık 4 saat kurutulması ile belirlenmiştir. Kül tayini için örneklere önce ön yakma işlemi uygulanmış ve ardından $550{ }^{\circ} \mathrm{C}$ de yaklaşık 5 saat kül firınında (ProthermFurnace ECO, 110/9, Ankara, Türkiye) yakılarak kül değerleri tespit edilmiştir. Kjeldahl azot tayin cihazı ile pestillerin proteinleri tayin edilmiştir. Pestillere ait ham yağ değerleri Sokslet cihazı kullanılarak petrol eteri ekstraksiyonuyla gerçekleştirilmiştir. Pestillerin su aktivitesi otomatik su aktivitesi tayin cihazi (LabSwift-aw, Novasina AG, Lachen, Almanya) ile belirlenmiştir. Örneklere ait renk değerleri ise $\left(L^{*}, a^{*}, b^{*}\right)$ Lovibond marka renk ölçüm cihazı ile tespit edilmiştir (The Tintometer Limited, İngiltere). Pestillerin suda çözünür kuru madde ( ${ }^{\circ}$ Briks) değerleri el refraktometresi ile belirlenmiştir (Atago, Pal-BX/RI, Japonya). Örneklerin titrasyon asitliği sitrik asit cinsinden (SSA) alkali titrasyon metodu ile tespit edilmiştir.

\subsection{Viskozite Tayini}

Viskozite değerleri için Kırmacı vd, (2014) de yaptıkları çalışma modifiye edilerek kullanılmıştır. Örneklerin viskozite değerleri için Şekil 1'e göre hazırlanan herleler kullanılmıştır. Analiz için örnekler $100 \mathrm{~mL}$ 'lik behere alınmış $70 \pm 3^{\circ} \mathrm{C}$ 'de analizleri gerçekleştirilmiştir. Analiz için J.P. Selecta Viskozimetresi (1001617, İspanya) kullanılmış, sonuçlar "Centipoise (cP)" olarak verilmiştir. Viskozimetre, 5 numaralı 
spindel ile $50 \mathrm{rpm}$ de çalıştırılmış ve her ölçüm 3 paralel olarak (60 saniye) gerçekleştirilmiştir.

\subsection{Sakkaroz, Glukoz, Fruktoz ve Toplam Şeker Tayini}

Örneklerden $5.0 \mathrm{~g}$ cam behere tart1lip $40 \mathrm{~mL}$ damıtık suda 1sitılmadan çözülmüştür. İçinde daha önceden $25 \mathrm{~mL}$ metanol bulunan $100 \mathrm{~mL}$ 'lik balon jojeye aktarıldıktan sonra hacmine kadar tamamlanmış olup daha sonra elde edilen çözelti 0.45 mikron membran filtreden süzülüp viallere aktarılmıştır. HPLC-UV-DAD-RID (Agilent 1100 seri, USA) HPLC cihazı (akış hızı: $1.3 \mathrm{~mL} / \mathrm{dk}$, hareketli faz Asetonitril/su (80:20) hacimsel olarak kolon sicaklığ $130^{\circ} \mathrm{C} \pm 1^{\circ} \mathrm{C}$, Enjeksiyon Hacmi: $20 \mu 1,250 \times 4.6$ mm ebadında, 5-7 mikron çapında amin gruplu modifiye edilmiş silikajel kolon) kullanılmıştır. Sonuçlar aşağıdaki formül kullanılarak \% (m/m) hesaplanmıştır (TS 13359).

$$
\% \text { Şeker }=\frac{A_{1} x V_{1} x m_{1} x 100}{A_{2} x V_{2} x m_{0}}
$$

Burada; A1: Örneğin her bir şeker için pik alanı, A2: Her bir standart'a ait pik alan1, V1: Numune çözeltisinin toplam hacmi, V2: Standart çözeltisinin toplam hacmi, m0: Numune kütlesi, g, m1: V2 (standart çözelti) hacmindeki şeker kütlesi, g

\subsection{HMF Tayini}

Örneklerden $5 \mathrm{~g}$ tartılmıştır. $50 \mathrm{~mL}$ balon jojeye aktarılmıs ve ardından $25 \mathrm{~mL}$ saf su ilave edilerek örneklerin çözülmesi sağlanmıştır. Daha sonra 0.5 mL Karrez I ve $0.5 \mathrm{~mL}$ KarrezII çözeltileri ilave edilerek huni yardımıyla süzülmüşlerdir. Çözeltiler 0.45 mikronluk filtreden geçilerek viallere alınmıștır. Miktar tayini için analitik standartla kalibrasyonu yapilarak HPLC-UVDAD (Agilent 1100 seri, USA) cihazı kullanılmıştır. Ayrım C18 kolon, $250 \mathrm{~mm} \times 4.6$ $\mathrm{mm}, 5 \mu \mathrm{m}$ (Nucleosil, USA) izokritik mobil faz: 90-10 (Su-Metanol), akış hızı: $1 \mathrm{~mL} /$ dakika, dalga Boyu: $285 \mathrm{~nm}$ UV-DAD detektörlü ve şartlanmış olan HPLC sistemine $100 \mu \mathrm{L}$ enjekte edilmiştir ( IHC 5.1, 2009). Numunedeki HMF miktarı standart ve numune çözeltileri pik alanlarına göre gerekli seyreltmelerde dikkate alınarak hesaplanmıştır. Örneklerin HMF içeriği $\mathrm{mg} / \mathrm{kg}$ olarak aşağıdaki bağıntı ile hesaplanmıştır.

$$
H M F \frac{m g}{k g}=\frac{V_{1}}{M} x \frac{1}{V_{2}} x\left(y-b_{0}\right) / m
$$

Burada; $\mathrm{V} 1=5 \mathrm{~g}$ örnekten naftalin ekstraksiyonu için kullanılan siklohekzanın hacmi, mL, V2 =HPLC' ye enjekte edilen çözelti hacmi, $\mathrm{mL}, \mathrm{m}=$ Numunesinin kütlesi, g, (y-b0) / m = kalibrasyon sabiti.

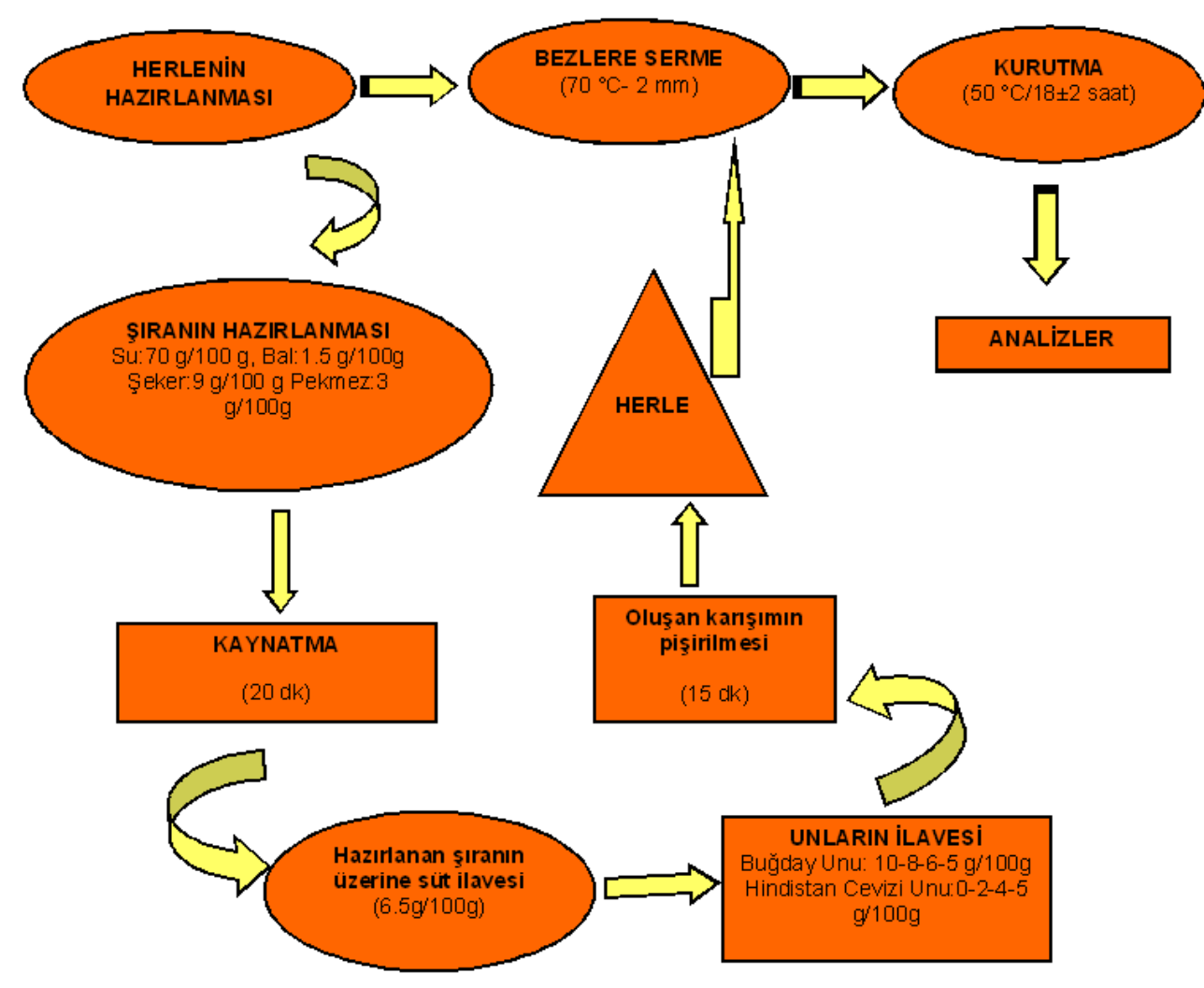

Şekil 1. Pestil üretim akım şemas1 


\subsection{Duyusal Analiz}

Pestiller duyusal analizleri Gümüşhane Üniversitesi gida mühendisliği bölümü öğrenci ve öğretim elemanları (30 panelist) tarafından gerçekleştirilmiştir. Duyusal analize başlamadan önce panelist gruba ürün hakkında bilgi verilmiştir ve daha sonra analiz gerçekleştirilmiştir. Örnekler rastgele kodlandiktan sonra yine rastgele servis edilmiştir. Örneklerin renk/görünüş ( 1 çok kötü; 9 çok iyi), ,tat/koku (1 çok kötü; 9 çok iyi), sertlik/yumuşaklık (1 çok yumuşak; 9 çok sert), yapışkanlık (1 çok az yapışkan; 9 çok yapışkan) ve genel beğeni ( 1 çok kötü; 9 çok iyi) bakımından duyusal değerlendirmeleri belirlenmeye çalışılmıştır. 1-9 aralığında skalanın kullanıldığı duyusal analizde panelistlere örnekler arasında su verilerek ağızlarını nötrlemeleri istenmiştir.

\section{8 Ístatistiksel Analiz}

Analiz sonuçlardan elde edilen veriler için tüm istatistiksel analizlerde SAS istatistiksel paket programının genel lineer model prosedürü kullanılmıştır (Version 8.2, SAS 2002; SAS Institute inc., Carry, NC, USA). Elde edilen verilerde sonuçlar üzerine faktörlerin etkisi varyans analizi ile tespit edilmiş, çoklu karşılaştırmalar ile grup ortalamaları karşılaştırılmıştır $(p<0.01$ ve $p<0.05)$.

\section{Bulgular ve Tartışma}

Tablo 2'de örneklere ait nem, $a_{w}$, kül, yağ, viskozite ve briks değerleri verilmiştir. Örneklere ait nem içeriklerinin Hindistan cevizi ununun formülasyondaki oranı arttıkça $\operatorname{arttığ1~ve~bu~}$ artışların istatistiksel olarak da önemli olduğu belirlenmiştir $(\mathrm{p}<0.01)$. Örneklere ait nem değerleri 11.65 ile $21.39 \mathrm{~g} / 100 \mathrm{~g}$ aralığında dağ 1 lım göstermiştir. Hindistan cevizi ununun örneklerin nem içeriklerini artırdığı saptanmıştır. Türk Standartları Enstitüsüne (TS 12677) göre pestillerde bulunması gereken nem miktarı en çok $18 \mathrm{~g} / 100 \mathrm{~g}$ dir (Anonimous 2000). Buna göre 4 numaralı örneğin $(21.39 \mathrm{~g} / 100 \mathrm{~g}$ nem) TSE'nin belirttiği sınır değeri aştığ Hindistan cevizi unu $10.9 \mathrm{~g} / 100 \mathrm{~g}$ oranında yă ve $12.1 \mathrm{~g} / 100 \mathrm{~g}$ protein içermesi, $60.9 \mathrm{~g} / 100 \mathrm{~g}$ diyet lifine sahip olması sayesinde üründe doğal bir nem bariyeri oluşturmaktadır (Trinidad vd., 2006). $\mathrm{Bu}$ sayede ürünlerin neminin muhafaza edildiği ve Hindistan cevizi ununun artması ile örneklerin nem içeriklerinin de arttığ düşünülmektedir. Yuksel vd., (2017) yılında yaptığı çalışmada pestil örneklerine katılan soya ununun örneklerin nem içeriklerini artırmasının soya unundaki protein ve yağdan kaynaklandığını belirtmişlerdir (Yuksel vd., 2017). Örneklerin su aktivitesi değerlerinin de nem içeriklerine benzer olarak Hindistan cevizi unu artışı ile önemli oranda arttığı tespit edilmiştir $(\mathrm{p}<0.01)$. Pestil örneklerine ait kül değerlerine baktığımızda, Hindistan cevizi ununun örneklerin kül içeriklerine olan etkisinin önemli olduğu görülmüştür $(\mathrm{p}<0.01)$. Hindistan cevizi unu 5.28 g/100g kül içermesi örneklerin kül içeriklerindeki artışın nedenini ortaya koymaktadır. Pestil örneklerinin kül değerleri sırasıyla şu şekilde bulunmuştur; 0.83-1.08-1.59 ve $1.62 \mathrm{~g} / 100 \mathrm{~g}$. Dut pestili için TSE' nin belirlediği kül miktarı en çok $4 \mathrm{~g} / 100 \mathrm{~g}$ olduğu göz önüne alındığında örneklerin standartlar içinde olduğu görülmektedir (Anonimous 2000). Hindistan cevizi atıkları üzerine yapılan bir araştırmada örneklerin kül içeriklerinin 0.6-8.2 g/100g arasında değiştiğ bulunmuştur (Yalegama vd., 2013). Bisküvilerin Hindistan cevizi unu ile zenginleştirildiği başka bir çalışmada da Hindistan cevizi ununun kül içeriğinin $8.2 \mathrm{~g} / 100 \mathrm{~g}$ olduğu belirtilmiştir (Sujirtha ve Mahendran, 2015). Hindistan cevizi unu ilavesinin örneklerin protein içeriklerinde önemli bir artış sağladığı belirlenmiştir $(\mathrm{p}<0.01)$. Örneklerin protein içerikleri sırasıyla şu şekilde tespit edilmiştir; 5.14-5.83-6.34-6.65 g/100g. Hindistan cevizi ununun protein içeriği 14.28 $\mathrm{g} / 100 \mathrm{~g}$ olduğu düşünüldüğünde $\operatorname{artan}$ konsantrasyonla beraber örneklerin protein içeriklerini artırdığı görülmektedir. Örneklerin yağ içerikleri $0.54-2.11 \mathrm{~g} / 100 \mathrm{~g}$ aralığında değişim göstermiş ve eklenen Hindistan cevizi ununun örneklerin yağ içerikleri üzerine etkisinin önemli olmadığ 1 tespit edilmiştir $(\mathrm{p}>0.05)$. Hindistan cevizi unun içermiş olduğu yağ miktarının örneklerdeki yă̆ içeriğini bir miktar artırdığ1 söylenebilir. Yapılan çalışmalarda Hindistan cevizi ununun yağ içeriğnin $10.9 \mathrm{~g} / 100 \mathrm{~g}$ (Trinidad vd., 2006) ve $9.2 \mathrm{~g} / 100 \mathrm{~g}$ (Yalegama vd., 2013; Sujirtha ve Mahendran, 2015) olduğu belirtilmiştir.

Herle pestil üretim aşamalarında bezlere serilmeden önceki kıvamlı yapının adıdır (Yıldız, 2013). Pestil üretiminde kullanılan tahıl bazlı bileşenler sayesinde herle kıvamını kazanmaktadır. Bu kıvamı sağlayan çoğu kez nişasta olmaktadır. Gümüşhane pestillerini diğerlerinden ayıran en önemli özellik ise tam nişasta unu yerine çoğu zaman buğday unu kullanılmasıdır. Bu sayede pestiller daha yumuşak kalmakta ve tüketiciler tarafindan daha çok beğenilmektedir. Herle oluşumunda en önemli bileşen nişasta ya da buğday unudur. 
Tablo 2. Örneklerin bazı fizikokimyasal özelliklerine ilişkin değerler

\begin{tabular}{|c|c|c|c|c|c|c|c|}
\hline Örnek & $\begin{array}{c}\text { Nem } \\
(\mathrm{g} / 100 \mathrm{~g})\end{array}$ & $\begin{array}{c}\text { Su } \\
\text { aktivitesi } \\
\left(\mathbf{a}_{\mathbf{w}}\right)\end{array}$ & $\begin{array}{c}\text { Kül } \\
\text { (g/100g) }\end{array}$ & $\begin{array}{l}\text { Protein } \\
(\mathrm{g} / \mathbf{1 0 0 g})\end{array}$ & $\underset{(\mathbf{g} / \mathbf{1 0 0 g})}{\text { Yağ }}$ & $\begin{array}{c}\text { Viskozite } \\
\text { (cP) }\end{array}$ & $\begin{array}{c}{ }^{0} \text { Briks } \\
\text { (Bx) }\end{array}$ \\
\hline 1 & $11.65 \pm 0.05^{\mathrm{a}}$ & $0.56 \pm 0.01^{\mathrm{c}}$ & $0.83 \pm 0.01^{\mathrm{c}}$ & $5.14 \pm 0.07^{\mathrm{d}}$ & $0.536 \pm 0.01^{\mathrm{a}}$ & $8305.3 \pm 0.70^{\mathrm{a}}$ & $28.90 \pm 4.38^{\mathrm{a}}$ \\
\hline 2 & $13.71 \pm 0.15^{\mathrm{b}}$ & $0.65 \pm 0.02^{\mathrm{b}}$ & $1.08 \pm 0.02^{\mathrm{b}}$ & $5.83 \pm 0.02^{\mathrm{c}}$ & $0.571 \pm 0.00^{\mathrm{a}}$ & $8293.65 \pm 2.05^{\mathrm{b}}$ & $28.90 \pm 3.32^{\mathrm{a}}$ \\
\hline 3 & $16.99 \pm 0.21^{\mathrm{c}}$ & $0.67 \pm 0.01^{\mathrm{b}}$ & $1.59 \pm 0.02^{\mathrm{a}}$ & $6.34 \pm 0.15^{\mathrm{b}}$ & $0.660 \pm 0.57^{\mathrm{a}}$ & $8290.25 \pm 2.75^{\mathrm{b}}$ & $29.45 \pm 0.77^{\mathrm{a}}$ \\
\hline 4 & $21.39 \pm 0.25^{\mathrm{d}}$ & $0.72 \pm 0.03^{\mathrm{a}}$ & $1.62 \pm 0.03^{\mathrm{a}}$ & $6.65 \pm 0.07^{\mathrm{a}}$ & $2.107 \pm 1.03^{\mathrm{a}}$ & $8288.8 \pm 6.22^{\mathrm{b}}$ & $30.75 \pm 0.95^{\mathrm{a}}$ \\
\hline
\end{tabular}

Herlenin kıvamlı yapı kazanması için nişastanın jelatinizasyon derecesi üzerinde 1sitılmas gerekmektedir ve bu sayede bezlere serilerek kurutulmaktadır. Buğday ununda yaklaşık 70 g/100g nişasta vardır (Van Der Borght vd., 2005). Pestillerin kurutulması esnasında nişastada oluşan retrogradasyon hadisesi ürünün sertliği ve depolama esnasındaki kuruma olayında önemli rol aldığı söylenebilir. Pestildeki nişasta oranının artmas1 ürünlerin sert bir hal almasina sebep olmaktadır. Üretimde buğday unu tercihi ile daha az nişasta oranına sahip olan Gümüşhane pestillerinin bu sebeple diğer pestillere göre daha yumuşak kaldığı söylenebilir. Viskozite pestil gibi ürünlerde içermiş olduğu nişasta gibi karbonhidratlardan direkt olarak etkilenmektedir. $\mathrm{Bu}$ etki ürünün pişirilmesi ve kurutulması esnasındaki jelatinizasyon ve retrogradasyon olayları hakkında önemli ipuçları vermektedir. Bu kapsamda yapılan viskozite analiz sonucuna göre örneklere ait viskozite değeleri sırasıyla şu şekilde tespit edilmiştir; 8305.3-8293.6-8290.2 ve 8288.8 cP. Şekil 2'de herlelerin viskozite değelerinin Hindistan cevizi unu artmas1 ile önemli oranda azaldığ1 görülmektedir $(\mathrm{p}<0.05)$. Bunun sebebinin Hindistan cevizi ununun eklenmesi ile formulasyondaki nişasta oranınının azalmasının olduğu söylenebilir. Hindistan cevizi unu özelliklerinin incelendiği bir çalışmada üründe nişasta bulunmadığ tespit edilmiștir (URL-2, 2018). Başka bir çalışmada Hindistan cevizi ununun $70.3 \mathrm{~g} / 100 \mathrm{~g}$ karbohidrat içerdiği ve bunun da $60.9 \mathrm{~g} / 100 \mathrm{~g}^{\prime} ı \mathrm{n}$ n toplam diyet lifi olduğu belirtilmiştir (Trinidad vd., 2006). Örneklere ait briks derecelerinde anlamlı bir değişim gözlemlenmemiştir ( $\mathrm{p}>0.05)$.

Hindistan cevizi unu ile zenginleștirilmiş pestil örneklerine ait renk $\left(L^{*}, a^{*} v e b^{*}\right)$ değerleri Tablo 3' de görülmektedir. Hindistan cevizi ununun örneklerin parlaklık $\left(L^{*}\right)$ değerlerine olan etkisi önemsiz bulunmuştur $(p>0.05)$. Pestil örneklerinin kırmızılık-yeşillik $\left(a^{*}\right)$ değerleri Hindistan cevizi unu ile önemli oranda artmış $(p<0.01)$ ve sırasıyla şu şekilde belirlenmiştir; 7.21,9.10, 12.18 ve 11.43. Sarılık-mavilik $\left(b^{*}\right)$ değerlerinin de $a^{*}$ değerleri gibi benzer şekilde arttı̆̆ tespit edilmiştir. Örneklerin $b^{*}$ değerleri 16.48 ile 29.37 aralığında değişim göstermiş olup, Hindistan cevizi ununun etkisi önemli bulunmuştur $(p<0.01)$. Renk sonuçlarındaki bu değişimler pişirme ile oluşan Maillard Reaksiyonu ve formülasyona katılan Hindistan cevizi ununun içermiş olduğu renk pigmentleri ile alakalı olduğu düşünülmektedir. Baltacı vd, (2016) da yaptıkları çalışmada herlelerin renk değerlerinin sıcaklığın $60{ }^{\circ} \mathrm{C}$ den $110^{\circ} \mathrm{C}^{\prime}$ ye kadar ki artışında parlaklığın $\left(L^{*}\right)$ 44.75-26.99 arasinda, kirmizilık $\left(a^{*}\right)$ değerlerinin 7.37-11.40 arasinda ve sarilık $\left(b^{*}\right)$ değerlerinin ise 14.48-23.11 arasında değiştiğini bulmuşlardır.

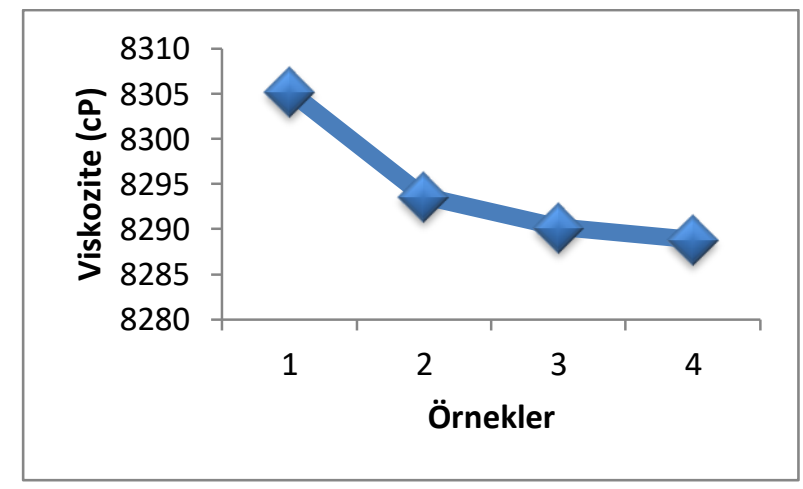

Şekil 2. Örneklerden elde edilen herlelerin viskozite değerleri

Tablo 3. Örneklere ait renk sonuçları

\begin{tabular}{cccc}
\hline Örnek & $\boldsymbol{L}^{*}$ & $\boldsymbol{a}^{*}$ & $\boldsymbol{b}^{*}$ \\
\hline $\mathbf{1}$ & $40.44 \pm 6.36^{\mathrm{a}}$ & $7.21 \pm 0.40^{\mathrm{c}}$ & $16.48 \pm 5.62^{\mathrm{b}}$ \\
$\mathbf{2}$ & $40.47 \pm 0.84^{\mathrm{a}}$ & $9.10 \pm 0.68^{\mathrm{b}}$ & $16.79 \pm 0.85^{\mathrm{b}}$ \\
$\mathbf{3}$ & $43.45 \pm 3.41^{\mathrm{a}}$ & $12.18 \pm 1.03^{\mathrm{a}}$ & $26.55 \pm 4.57^{\mathrm{a}}$ \\
$\mathbf{4}$ & $44.36 \pm 3.02^{\mathrm{a}}$ & $11.43 \pm 1.10^{\mathrm{a}}$ & $29.37 \pm 3.17^{\mathrm{a}}$ \\
\hline$* p<0.01, * * p<0.05$ & &
\end{tabular}

Örneklerin asitlik, HMF ve şeker analizi sonuçları Tablo 4' de verilmiştir. Örneklerin asitlik değerleri sitrik asit cinsinden (SSA) hesaplanmış olup, formülasyona $4 \mathrm{~g} / 100 \mathrm{~g}$ Hindistan cevizi unu ilavesine kadar değişim gözlemlenmemişken 5 $\mathrm{g} / 100 \mathrm{~g}$ Hindistan cevizi unu ile asitliğin önemli oranda düştügü belirlenmiştir $(p<0.01)$. En yüksek 
asitlik \% 0.22 ve en düşük asitlik \% 0.15 olarak belirlenmiştir. TSE'ne göre dut pestilinde bulunması gereken asitliğin en çok $\% 0.2$ olduğu göz önüne alındığında örneklerin asitlik değerlerinin bu sınıra uyduğu belirlenmiştir (Anonimous, 2000). Pestil örneklerine ait HMF değerleri sırasiyla; 11.64-21.55-17.98 ve 11.21 $\mathrm{mg} / \mathrm{kg}$ olarak belirlenmiştir. Pestil örneklerinden 2 numaranın en yüksek HMF değerine sahip olduğu görülürken en düşük HMF değeri ise 4 numaraları pestil örneğinde tespit edilmiştir. İstatistiksel olarak örneklerin HMF değerleri arasındaki farklar önemli bulunsa da $(p<0.01)$ pestil örneklerinde ölçülen HMF değerlerinin TSE'ne göre pestillerde bulunması gereken maksimum HMF değerinin $(50 \mathrm{mg} / \mathrm{kg})$ çok altında olduğu görülmektedir (Anonimous, 2000). Aralarındaki farklılıkların üretim esnasındaki insan hatası ve diğer etmenlerden kaynaklandığı söylenebilir. Yıldız (2013) de yaptığ çalışmada pestil örneğinin HMF değerini $27.94 \mathrm{mg} / \mathrm{kg}$ olarak bulmuştur. Yapılan başka bir çalışmada Gümüşhane pestillerindeki HMF içeriklerinin 22.45 ile $25.27 \mathrm{mg} / \mathrm{kg}$ arasında olduğu belirtilmiştir (Baltacı vd., 2016). Pestil örneklerinin fruktoz ve glukoz miktarları arasındaki farklılıkların istatistiksel olarak önemli olmadığı tespit edilmiştir $(p>0.05)$. Sakkaroz miktarları arasındaki farklılıkların ise önemli olduğu ve en yüksek sakkaroz miktarına (\%27.63) 1 numaralı kontrol örneğinin sahip olduğu tespit edilmiştir $(p<0.01)$. Toplam şeker içeriği bakımından 2 numaralı örneğin en düşük şeker içeriğine (\% 30.26) sahip olduğu ve farklılıkların istatistiksel bakımdan önemli olduğu tespit edilmiştir $(p<0.05)$. Örneklerin şeker içeriklerinin birbirine oldukça yakın olduğu, her ne kadar bazılarında istatistiksel sonuçlar önemli çıksada miktarsal anlamda çok fark olmadığı belirlenmiştir. Pestil örneklerinin şeker içeriklerinin formülasyona katılan şeker, bal, pekmez ve bir miktar undan kaynaklandığ1 söylenebilir. Hindistan cevizi ununun şeker içeriğinin $1.9 \mathrm{~g} / 100 \mathrm{~g}$ olduğu bildirilmiştir (URL2, 2018). Gümüşhane herlesi üzerine yapılan bir çalışmada herledeki fruktoz içeriğinin \% 11.9, glukozun $\% 9.6$ ve toplam şekerin $\% 22$ olduğu belirtilmiştir (Baltacı vd., 2016). Çalışmadaki sonuçlar ile farklılığın formülasyondan kaynaklandığı düşünülmektedir.

Örneklere ait duyusal sonuçlar Tablo $5^{\prime}$ de verilmiştir. Pestil örneklerinin renk/görünüş, sertlik/yumuşaklık, yapışkanlık ve genel beğeni sonuçları üzerine Hindistan cevizi ununun etkisi önemsiz bulunmuştur $(p>0.05)$. Sadece koku/tat sonuçları panelistlerin verdiği skorlar neticesinde önemli bulunmuştur $(p<0.05)$.

30 panelist gibi yüksek sayıda katılımcı ile yapılan duyusal analizde sonuçların önemsiz çıkmasına rağmen 2 numaralı örnek $(2 \mathrm{~g} / 100 \mathrm{~g}$ Hindistan cevizi unu içeren formulasyon) tüm panelistlerce en yüksek skorları almış ve en beğenilen deneme noktası olmuştur.

Tablo 4. Örneklere ait asitlik, HMF ve şeker değerleri

\begin{tabular}{ccccccc}
\hline Örnek & $\begin{array}{c}\text { Asitlik } \\
(\boldsymbol{\%}) \mathbf{S S A}\end{array}$ & $\begin{array}{c}\text { HMF } \\
(\mathbf{m g} / \mathbf{k g})\end{array}$ & $\begin{array}{c}\text { Fruktoz } \\
(\boldsymbol{\%})\end{array}$ & $\begin{array}{c}\text { Glukoz } \\
(\boldsymbol{\%})\end{array}$ & $\begin{array}{c}\text { Sakkaroz } \\
(\boldsymbol{\%})\end{array}$ & $\begin{array}{c}\text { Toplam } \\
\text { şeker } \\
(\boldsymbol{\%})\end{array}$ \\
\hline $\mathbf{1}$ & $0.21 \pm 0.01^{\mathrm{a}}$ & $11.64 \pm 0.45^{\mathrm{c}}$ & $3.51 \pm 0.20^{\mathrm{a}}$ & $1.91 \pm 0.07^{\mathrm{b}}$ & $27.63 \pm 0.84^{\mathrm{a}}$ & $33.03 \pm 1.10^{\mathrm{a}}$ \\
$\mathbf{2}$ & $0.22 \pm 0.01^{\mathrm{a}}$ & $21.55 \pm 1.35^{\mathrm{a}}$ & $3.41 \pm 0.19^{\mathrm{a}}$ & $2.24 \pm 0.19^{\mathrm{a}}$ & $24.61 \pm 1.16^{\mathrm{c}}$ & $30.26 \pm 1.24^{\mathrm{b}}$ \\
$\mathbf{3}$ & $0.21 \pm 0.01^{\mathrm{a}}$ & $17.98 \pm 0.61^{\mathrm{b}}$ & $3.61 \pm 0.14^{\mathrm{a}}$ & $2.02 \pm 0.08^{\mathrm{ab}}$ & $27.10 \pm 0.31^{\mathrm{ab}}$ & $32.69 \pm 0.29^{\mathrm{a}}$ \\
$\mathbf{4}$ & $0.15 \pm 0.01^{\mathrm{b}}$ & $11.21 \pm 0.21^{\mathrm{c}}$ & $3.65 \pm 0.11^{\mathrm{a}}$ & $2.17 \pm 0.13^{\mathrm{a}}$ & $26.14 \pm 0.18^{\mathrm{b}}$ & $31.96 \pm 0.18^{\mathrm{a}}$ \\
\hline$* p<0.01, * * p<0.05$ & & & & &
\end{tabular}

Tablo 5. Örneklere ait duyusal sonuçlar

\begin{tabular}{cccccc}
\hline Örnek & Renk/Görünüş & Koku/Tat & Sertlik/Yumuşaklık & Yapışkanlık & Genel Beğeni \\
\hline $\mathbf{1}$ & $5.50 \pm 2.04^{\mathrm{ab}}$ & $4.73 \pm 1.84^{\mathrm{b}}$ & $5.40 \pm 2.62^{\mathrm{ab}}$ & $4.77 \pm 2.08^{\mathrm{ab}}$ & $5.03 \pm 1.94^{\mathrm{ab}}$ \\
$\mathbf{2}$ & $6.47 \pm 1.48^{\mathrm{a}}$ & $6.03 \pm 1.67^{\mathrm{a}}$ & $6.23 \pm 1.61^{\mathrm{a}}$ & $5.10 \pm 1.91^{\mathrm{a}}$ & $6.03 \pm 1.84^{\mathrm{a}}$ \\
$\mathbf{3}$ & $5.37 \pm 2.31^{\mathrm{b}}$ & $4.83 \pm 2.36^{\mathrm{b}}$ & $4.87 \pm 2.57^{\mathrm{b}}$ & $3.76 \pm 2.21^{\mathrm{b}}$ & $4.83 \pm 2.26^{\mathrm{b}}$ \\
$\mathbf{4}$ & $5.27 \pm 2.01^{\mathrm{b}}$ & $4.83 \pm 1.91^{\mathrm{b}}$ & $5.77 \pm 2.05^{\mathrm{ab}}$ & $4.63 \pm 1.94^{\mathrm{ab}}$ & $5.43 \pm 1.74^{\mathrm{ab}}$ \\
\hline p $^{\mathrm{b}}<0.01, * * p<0.05$ & & &
\end{tabular}




\section{Sonuç}

Pestil başta Gümüşhane şehri olmak üzere ülkemize ait önemli bir geleneksel gidadır. Önemli ihracat potansiyeli olan bu ürünün Hindistan cevizi unu ile üretilerek, özelliklerinin incelendiği bu çalışma sayesinde pestil sektörü alternatif bir üretim formülasyonu kazanmıştır. Örneklerin nem, kül ve protein içerikleri Hindistan cevizi unu ile önemli oranda artmıştır. Herledeki viskozite değerlerinin önemli şekilde azaldığ 1 tespit edilmiştir. HMF ve şeker içerikleri bakımından TSE'nin belirttiği sınırlar içinde olduğu anlaşılmıştır. Duyusal değerlendirme bulgularına göre pestil üretiminde $2 \mathrm{~g} / 100 \mathrm{~g}$ ' lik bir Hindistan cevizi unu ilavesi ile daha yumuşak, daha iyi koku/tat'1 olan ve genel anlamda kabul görmüş TS'ye uygun pestil üretilebileceği bu çalışma ile ortaya konmuştur.

\section{Kaynaklar}

Amoo, I.A., 2004. Effect of roasting on the chemical composition of coconut (Cocos nucifera) seed flour and oil. J Food Agric Environ., 2, 18-20.

Anonimous, 2000. TS 12677/Ekim 2000, Dut pestili. Türk standardı, Ankara

AOAC., 2000. Official Methods of Analysis, 17th Ed., Association of Official Analytical Chemists, Inc., Arlington, VA.

Baltacı, C.,Ilyasoglu, H., Gundogdu, A. ve Ucuncu, O., 2016. Investigation of Hydroxymethylfurfural Formation in Herle. Int J Food Prop., 19, 27612768.

Batu, A., Kaya, C., Çatak, J. ve Sahin, C., 2007. Pestil Üretim Tekniği. Gıda Teknolojileri Elektronik Dergisi, 1, 71-81

Becerikli, F.,Başoğul, F., 2018. Geleneksel ürünlerimizden olan köftürün bazı biyoaktif, fizikokimyasal ve kimyasal özellikleri. Gıda, 43 (2), 356-363.

Berksoy, B.O., Berksoy, M., Demirdağ, Y. ve Suran, F., 2016., Gümüşhane pestil ve köme ile dünyaya açılıyor " projesi ur ge ihtiyaç analizi raporu. Gümüşhane Ticaret ve Sanayi Odası 102 s.

Ekşi, A. ve Artık, N., 1984. Pestil işleme tekniği ve kimyasal bileşimi. Gıda, 9, 263-266.

Igbabul, B.D.,Bello, F.A. ve Ani, E.C., 2014. Effect of fermentation on the proximate composition and functional properties of defatted coconut (Cocos nucifera L.) flour. Sky J Food Sci., 3, 34 - 40.
Kalkıșım, Ö. ve Özdemir, M., 2012. Pestil ve köme teknolojisi. Gümüşhane Üniversitesi Yayınları, $95 \mathrm{~s}$.

Kırmacı, H.A.,Kuşcu, H. ve Atasoy, F. 2014. Farklı oranlarda prebiyotik lif içeren stevia özü ilavesinin probiyotik dondurmanın kalite özellikleri etkisi. Harran Tarım ve Gıda Bilimleri Dergisi, 18 (3), 48-59.

Sujirtha, N. veMahendran, T., 2015. Use of Defatted Coconut Flour as a Source of Protein and Dietary Fibre in Wheat Biscuits. Int $\mathbf{J}$ Innovative Res Sci Eng Technol., 4, 7344-7352.

TPE. 2004. Gümüşhane dut pestili. Turkish Patent Institutue.

Trinidad, T.P.,Mallillin, A.C., Valdez, D.H., Loyola, A.S., Askali-Mercado, F.C., Castillo, J.C., Encabo, R.R., Masa, D.B., Maglaya, A.S. ve Chua, M.T., 2006. Dietary fiber from coconut flour: A functional food. Innovative Food Sci Emerg Technol., 7, 309-317.

URL-1, 2017.

https://www.aa.com.tr/tr/ekonomi/turkiyeninpestil-ve-komesi-gumushaneden/891710, (07.07.2017).

URL-2, 2018.

http://nutritiondata.self.com/facts/custom/59139 $2 / 2,(06.06 .2018)$.

Van Der Borght, A.,Goesaert, H. ve Veraverbeke, W.S., 2005. Delcour J.A., Fractionation of wheat and wheat flour into starch and gluten: overview of the main processes and the factors involved. J Cereal Sci., 41, 221-237.

Yalegama, L.L.W.C.,Karunaratne, D.N., Sivakanesan, R. ve Jayasekara, C., 2013. Chemical and functional properties of fibre concentrates obtained from by-products of coconut kernel. Food Chem., 141, 124-130

Yıldız, O., 2013. Physicochemical and sensory properties of mulberry products: Gümüşhane pestil and köme. Turk J AgricFor.,37, 762-771.

Yuksel, F., Gudelek, T. ve Baltaci, C., 2017. Pestil (grape leather) enriched with wheat and soy flour: some physiochemical and sensory properties. International congress on medicinal and aromatic plants natural and healthy life, 740 s, Konya/Turkey.

Zhenga, Y.ve Lia, Y., 2018. Physicochemical and functional properties of coconut (Cocos nucifera L.) cake dietary fibres: Effects of cellulase hydrolysis, acid treatment and particle size distribution. Food Chem., 257, 135-142. 